\title{
INTERVENSI RASA BERSYUKUR UNTUK MENINGKATKAN HARGA DIRI REMAJA DI SMP X
}

\author{
Novia Sri Parindu Purba ${ }^{1}$, Riana Sahrani ${ }^{2}$, Heni Mularsih $^{3}$ \\ ${ }^{1}$ Program Studi Psikologi Profesi Jenjang Magister, Universitas Tarumanagara, Jakarta \\ Email: novia.717172022@stu.untar.ac.id \\ ${ }^{2}$ Fakultas Psikologi, Universitas Tarumanagara, Jakarta \\ Email: rianas@fpsi.untar.ac.id \\ ${ }^{3}$ Fakultas Psikologi, Universitas Tarumanagara, Jakarta \\ Email:henim@mku.untar.ac.id
}

Masuk : 10-04-2020, revisi: 28-04-2020, diterima untuk diterbitkan : 30-04-2020

\begin{abstract}
Low self-esteem is also associated with poverty, it is necessary to have an effort to accept the conditions of life first. One of the simple characteristics of the acceptance effort is gratitude. Gratitude is a strong predictor to increase hope and happiness in adolescents who experience poverty. This research was designed as experimental group in $X$ secondary school. The group was consisted of 6 respondents without a control group. The design of this study was a quasi-experimental (one group pretest-posttest) using the Rosenberg Self-esteem scale (RSSE) with a reliability coefficient of 0.88. The implementation of the gratitude intervention was designed using an intervention module from the aspect of the Indonesian grateful scale (SBI) and it was neither just a list of words of gratitude nor gratefulness. This gratitude intervention is done by inviting participants to focus on positive aspects of life, exploring positive emotions by recalculating the blessings of life that have been received from God and others. To sum up, these findings provide new findings in the use of gratitude intervention that focuses on the divine aspect. The results of this study indicate that there are significant differences in respondent's self-esteem before and after administration of the gratitude intervention, with self-esteem (RSSE) (Asymp. Sig. (2-tailed) $=0.042, p<0.05)$. This discussion focuses on the implications generated for Gratitude literature which are adapted to Indonesian cultural values.
\end{abstract}

Keywords: adolescents; gratitude intervention; poverty; self-esteem

\begin{abstract}
ABSTRAK
Harga diri yang rendah juga terkait dengan kemiskinan, maka diperlukan adanya usaha penerimaan kondisi kehidupannya terlebih dahulu. Salah satu karakteristik sederhana sebagai upaya penerimaan tersebut yakni dengan rasa bersyukur. Rasa bersyukur merupakan prediktor yang kuat untuk meningkatkan harapan dan kebahagiaan pada remaja yang mengalami kondisi miskin sekalipun. Penelitian ini diberikan kepada satu kelompok eksperimen yang terdiri dari 6 responden tanpa adanya kelompok kontrol di salah satu sekolah menengah pertama (SMP) terbuka X di Jakarta Utara. Desain penelitian ini merupakan quasi eksperimen (one group pretest-posttest) dengan menggunakan Rosenberg Self-esteem scale (RSSE) dengan hasil koefisien reliabilitas sebesar 0.88. Pelaksanaan pelatihan rasa bersyukur ini dirancang dengan menggunakan modul intervensi dari aspek skala bersyukur Indonesia (SBI) dan bukan hanya sekedar daftar ucapan rasa bersyukur atau terimakasih. Pelatihan kebersyukuran ini dilakukan dengan mengajak partisipan untuk fokus terhadap aspek positif dalam hidup, mengeksplorasi emosi positif dengan menghitung kembali berkah kehidupan yang telah diterima dari Tuhan dan orang lain. Singkatnya, temuan ini memberikan temuan baru dalam penggunaan intervensi rasa bersyukur yang berfokus pada aspek keTuhanan. Hasil penelitian ini menunjukkan bahwa terdapat perbedaan yang signifikan pada harga diri responden sebelum dan sesudah pemberian pelatihan kebersyukuran, dengan nilai self-esteem (RSSE) (Asymp. Sig. (2-tailed) $=0.042$, p $<0.05$ Diskusi ini berfokus pada implikasi yang dihasilkan untuk literature bersyukur yang disesuaikan dengan nilai-nilai budaya Indonesia.
\end{abstract}

Kata Kunci: harga diri; intervensi gratitude; kemiskinan; remaja.

\section{PENDAHULUAN}

Fenomena perilaku negatif erat kaitannya dengan kemiskinan dan relasi kuasa. Selain itu, diskriminasi merupakan pengalaman yang biasa dialami oleh masyarakat yang hidup dalam kemiskinan. Banyak orang secara tidak adil mengaitkan kemiskinan dengan kemalasan dan sifat negatif lainnya, dan stereotip atau prasangka ini mungkin memiliki efek yang merugikan pada 
harga diri orang-orang yang berada dalam garis kemiskinan (W. Chen et al., 2016). Mereka yang berada dalam garis kemiskinan juga berada dalam ketidakpastian yang lebih tinggi hingga dapat menimbulkan banyak peristiwa dan stress yang mengancam.

Apalagi dibandingkan dengan anak-anak, remaja lebih sensitif kesenjangan antara miskin dan kaya karena pesatnya perkembangan sosial dan kesadaran diri di masa remaja. Rosenberg dan Pearlin (dalam Chen et al., 2016) meneliti hubungan antara kelas sosial dan harga diri dalam sampel anakanak berusia 8-18 tahun, dan hasilnya menunjukkan remaja lebih berpengaruh terhadap tingkatan kelas sosial dibandingkan anak-anak. Dengan demikian kemiskinan merupakan faktor prediktif yang memengaruhi harga diri seseorang, terutama pada remaja.

Peneliti melakukan studi yang dilakukan di sekolah menengah pertama (SMP) terbuka X Jakarta Utara dengan status sosial ekonomi menengah ke bawah. Hasil wawancara peneliti dengan Kepala sekolah dan guru menjelaskan bahwa rata-rata siswa-siswi mereka mengalami permasalahan harga diri. Disamping itu juga, menurut pihak sekolah X latar belakang keluarga siswa/i mereka kebanyakan berasal dari keluarga broken home, memiliki banyak saudara, dan kehidupan keluarga yang terlilit utang dan berbagai faktor lingkungan yang kurang mendukung.

Fakta yang terjadi juga, permasalahan harga diri tersebut memberikan dampak rata-rata siswa/i mereka memilih untuk menikah muda, hamil di luar nikah, terlibat geng motor, rendahnya motivasi berprestasi dan kesulitan untuk berinteraksi dengan orang lain. Hasil survey yang dilakukan oleh komunitas peduli kesehatan jiwa di tahun 2018 di sekolah X, menunjukkan bahwa dari 113 siswa SMP X, $15 \%$ dari mereka mengalami depresi dan 30\% mengalami kecemasan. Rosenberg et al., dalam Veselska et al., (2010) menjelaskan bahwa depresi dan kecemasan sering dikaitkan dengan harga diri.

Remaja mengalami penurunan harga diri dikaitkan dengan adanya perubahan yang signifikan selama masa transisi dari masa kanak-kanak hingga masa remaja (Bos, Muris, Mulkens \& Schaalma, dalam Beta Oktalia, Tiatri, \& Mularsih, 2018). Pada tahap perkembangan ini, harga diri remaja mengalami perubahan penting, tidak hanya dipengaruhi oleh status sosial ekonomi yang telah disebutkan, tetapi juga oleh berbagai faktor penentu intrapersonal, interpersonal dan sosiokultural lainnya (Finkenauer, Engels, Meeus \& Oosterwegel, dalam Veselska et al., 2010).

Remaja juga harus melewati masa kompetensi kognitif dan emosional, otonomi, harga diri dan intimasi (Ormrod, Anderman, \& Anderman, 2017), sedangkan harga diri menjadi salah satu faktor penting untuk perkembangan masa remaja. Remaja yang berada dalam kondisi kehidupan yang miskin mengalami sulitnya mendapatkan akses terhadap lembaga pendidikan yang bermutu (Markum, 2009). Tingkat pendidikan orang tua dan pendapatan keluarga, secara tidak langsung berdampak pada pencapaian pendidikan dan keterikatan akademis remaja (Papalia, E \& Feldman, Ruth, 2014). Mereka lebih peduli pada kebutuhan dasar, dan tidak terlalu menekankan prestasi akademik anak-anak mereka (Sang, 2015).

Akibat dari harga diri yang rendah menjadi salah satu faktor utama yang menyebabkan anak-anak menjadi pengganggu (child bullies) (Frisen, Jonsson, \& Persson, dalam Fanti \& Henrich, 2015). Temuan lain juga mengatakan bahwa harga diri rendah dianggap menjadi prediktor munculnya permasalahan pada masa dewasa (Simpson-Scott, 2009). Siswa yang rendah diri menyebabkan faktor risiko untuk agresi dan perilaku antisosial (Fanti \& Henrich, 2015), dan masalah personal lainnya seperti rasa malu (shyness), kesepian, keterasingan, rendahnya performansi di sekolah, depresi, melukai diri sendiri, bunuh diri, (Aunillah \& Adiyanti, 2015). Selain itu, rendahnya harga 
diri juga berdampak pada masalah sosial, seperti kenakalan remaja, kekerasan, kriminalitas, dan penggunaan obat terlarang ((Aunillah \& Adiyanti, 2015), masalah perilaku dan kinerja sekolah yang buruk (Orth \& Robins, 2013).

Berbagai penelitian yang telah dilakukan menunjukkan bahwa harga diri yang tinggi meningkatkan tujuan, harapan, mekanisme koping, dan achievement serta menghambat masalah kesehatan mental dan fisik, penyalahgunaan zat, dan perilaku antisosial (Trzesniewski et al., 2006). Dibandingkan individu dengan harga diri yang rendah memiliki tingkat vitalitas dan kesenangan yang rendah, tidak percaya diri, merasa malu, perasaan tidak berharga dan tidak mampu dalam hal keberhasilan dan keterampilan (Karadağ, 2017). Dengan demikian, diperlukan adanya usaha untuk meningkatkan harga diri pada siswa-siswi di sekolah X. Peneliti melihat adanya kesesuaian dengan fenomena, yaitu pemberian intervensi rasa bersyukur dalam meningkatkan harga diri siswa-siswi sekolah $\mathrm{X}$ yang berada dalam garis kemiskinan.

Rasa syukur (gratitude) dijelaskan dapat meningkatkan tingkat harga diri, kepercayaan diri, moral, etika (McCullough et al., dalam Amin, 2018). Rash, Matsuba, \& Prkachin (2011) yang menjelaskan bahwa individu dengan rasa bersyukur tinggi lebih mudah untuk merasakan ucapan terimakasih dengan emosi yang positif, dan pengalaman terima kasih lebih banyak setiap harinya dalam berbagai keadaan. Rasa bersyukur memiliki komponen emosional, kognitif dan perilaku yang memiliki keterkaitan yang kompleks di antara mereka (Ghosh \& Deb, 2017). Bersamaan dengan ini, bersyukur juga digambarkan sebagai kebajikan moral, kebiasaan, sifat kepribadian, dan strategi koping (McCullough et al., 2001).

Remaja yang selalu bersyukur cenderung memiliki empati, menjadi pemaaf, dan dipercaya (Uhder et al., 2018). Mereka juga akan mampu untuk mempersepsikan kesenangan sehari-hari yang sederhana (Uhder et al., 2018). Respon bersyukur terhadap kehidupan dapat menuntun remaja pada ketenangan pikiran, kebahagiaan, kesehatan fisik, dan hubungan pribadi yang dalam dan lebih memuaskan (Uhder et al., 2018). Oleh sebab itu, Mruk menjelaskan harga diri dapat dibangun dengan cara memberikan umpan balik positif tentang diri atau perilaku mereka, yang juga dapat dilakukan melalui kebersyukuran (Mruk, 2006).

Studi sebelumnya tentang harga diri dilakukan dengan pembuatan jurnal bersyukur yang melibatkan anak jalanan. Pada penelitian ini responden penelitian menuliskan jurnal bersyukur terdiri dari tujuh poin mengenai pengalaman-pengalaman positif yang dirasakan. Menuliskan jurnal bersyukur secara rutin mengenai pengalaman-pengalaman positif dan bahagia yang dirasakan dalam kehidupan sehari-sehari dapat mengubah keraguan dan dapat membuat harga diri seseorang meningkat (Grimaldy et al., 2018). Hal ini disebabkan individu yang bersyukur lebih cenderung memiliki evaluasi diri yang lebih tinggi, dan dengan demikian mengalami kesejahteraan yang lebih besar (McCullough et al., dalam Kong et al., 2015).

Penelitian intervensi yang sering diteliti dengan gratitude list, di mana partisipan diminta untuk menuliskan tiga hingga lima hal yang disyukuri selama hari itu. Intervensi ini merupakan teknik sederhana dan cepat yang menunjukkan hasil peningkatan pada efek positif, kebahagian dan kepuasan hidup dan menurunkan gejala depresi (Cunha et al., 2019). Hasil analisis keefektifan pada dewasa awal yang mengalami peningkatan yang signifikan yang memengaruhi dan menurunkan gejala depresi setelah mengikuti intervensi reflective-behavioral gratitude journal (O’Connell et al., 2017). 
Pada dasarnya, penggunaan intervensi dengan menuliskan jurnal bersyukur merupakan teknik sederhana yang dapat digunakan dalam pengaturan klinis dan mudah bagi peserta untuk terus berlatih di masa depan (Emmons \& McCullough, dalam Gabana, Steinfeldt, Wong, Chung, \& Svetina, 2018). Pada penelitian-penelitian sebelumnya alat ukur bersyukur yang ada dan dikembangkan di negara lainnya, pada umumnya menghilangkan aspek ketuhanan (Listiyandini et al., 2015). Oleh karena itu, pada penelitian ini peneliti tertarik untuk merancang intervensi dengan menggunakan modul intervensi dari Skala Bersyukur Indonesia (SBI) yang telah diadaptasi (Nadya et al., 2017). Dengan demikian, rancangan yang diberikan disesuaikan dengan karakter bangsa Indonesia yang dibangun di atas landasan ketuhanan.

Rancangan penelitian diberikan dengan memfokuskan pada aspek positif dalam hidup, mengeksplorasi emosi positif dengan menghitung kembali berkah kehidupan yang telah diterima dari Tuhan dan orang lain. Selama pelaksanaan intervensi juga responden diberikan tugas harian yang dikerjakan di buku harian bersyukur rancangan dari peneliti yang disesuaikan dengan aitem SBI. Intervensi rasa bersyukur diberikan dengan banyak melibatkan interaksi antar sesama partisipan, peneliti, maupun orang lain. Pelatihan ini juga memberikan kesempatan kepada siswa untuk merenungkan manfaat yang telah diterima dan jika tanpa sebuah berkah. Dengan demikian, dapat dibuktikan adanya peran intervensi rasa bersyukur terhadap peningkatan harga diri remaja di salah satu Sekolah Menengah Pertama (SMP) X di Jakarta Utara.

\section{METODE PENELITIAN}

Partisipan dalam penelitian ini diambil dengan metode purposive sampling, dengan kriteria partisipan merupakan siswa dari SMP Terbuka X berusia 12-18 tahun, memiliki skor harga diri yang tergolong kategori rendah. Partisipan termasuk siswa yang berada dalam keadaan keluarga yang termasuk dalam keluarga sejahtera I atau miskin, dengan gambaran demografi dari keluarga responden memiliki profesi pekerjaan tanpa keterampilan khusus (seperti buruh, supir dan petugas kebersihan). Rata-rata pendidikan orangtua tamatan sekolah dasar (SD), dan hanya tertinggi adalah Sekolah Menengah Pertama (SMP). Rata-rata pemasukan bulanan adalah di bawah Standar Upah Minimum Regional (UMR) DKI Jakarta. Selain itu, partisipan diharapkan bersedia mengikuti intervensi rasa bersyukur (gratitude) selama delapan sesi pertemuan.

Penelitian ini merupakan penelitian kuasi-eksperimen dengan metode pre-eksperimen (preexperimental research), yaitu one group pretest-posttest design. Berikut bagan dari desain ini:

$$
\text { Pengukuran }\left(\mathrm{O}_{1}\right) \longrightarrow \text { Manipulasi }(\mathrm{X}) \longrightarrow \text { Pengukuran }\left(\mathrm{O}_{2}\right)
$$

Desain penelitian ini peneliti mengamati satu kelompok siswa terpilih untuk diberikan intervensi, yang terdiri dari tiga siswa putra dan tiga siswi putri. Dalam rancangan ini, tidak ada kelompok kontrol untuk dibandingkan dengan kelompok eksperimen. Desain ini dilakukan dengan memberikan pengukuran (Rosenberg self esteem scales), berada di coeffisient alphas .72 hingga .88 (Beta Oktalia et al., 2018) sebelum diberikannya perlakuan pada suatu kelompok. Partisipan diminta untuk untuk menilai aitem ("Secara keseluruhan, saya puas dengan diri saya sendiri"), ("Terkadang, saya merasa bahwa diri saya tidak baik"), ("Saya merasa memiliki sejumlah kualitas diri yang baik") dengan menggunakan skala Likert 4 poin mulai dari 1 (sangat tidak setuju) hingga 4 (sangat setuju). Alat ukur yang digunakan dalam penelitian diadaptasi ke dalam Bahasa Indonesia oleh (Betta Oktalia, 2018) yang selanjutnya akan digunakan dalam penelitian ini. 
Dengan demikian hasil perlakuan dapat diketahui lebih akurat karena dapat membandingkan dengan keadaan sebelum diberi perlakuan. Pada desain ini, dilakukan pengukuran terhadap variabel terikat yaitu harga diri (self-esteem). Selanjutnya diberikan manipulasi atau treatment intervensi rasa bersyukur (gratitude), dilanjutkan dengan pengukuran kembali terhadap variabel terikat (VT) dengan dengan alat ukur yang sama. Efektivitas atau pengaruh dari dependent variabel $(\mathrm{VB})$ terhadap VT dilihat dari perbedaan antara pretest $\left(\mathrm{O}_{1}\right)$ dengan posttest $\left(\mathrm{O}_{2}\right)$.

Definisi operasional intervensi rasa bersyukur (gratitude) dalam penelitian ini adalah suatu pelatihan yang ditandai dengan adanya pembentukan rasa apresiasi terhadap Tuhan ataupun orang lain, memiliki pandangan yang positif terhadap kehidupan yang dimiliki, dan menerapkan atau bertindak secara konkrit sebagai wujud ekspresi dari perasaan positif dan apresiasi yang dimilikinya. Definisi operasional dari harga diri (self-esteem) diambil dari Rosenberg, yang meliputi merasa tidak puas, kurang kompetensi, kurang inisiatif, penuh dengan konflik (marah, sedih), sulit untuk berinteraksi, penuh kehati-hatian, berpikiran negatif dan bersikap negatif (Rash et al., 2011).

Prosedur pelaksanaan intervensi terdiri dari tiga tahapan, yakni tahap pembukaan (ice breaking), materi, dan penutup. Perlakuan yang dilakukan pada kelompok eksperimen di setiap sesinya berbeda-beda. Peneliti memberikan materi dengan menerapkan beberapa jenis startegi/metode pembelajaran, seperti ceramah dan diskusi, field trip, role play, sosiodrama, dan latihan keterampilan. Pada sesi awal intervensi, peneliti memberikan materi yang berhubungan dengan harga diri dan rasa bersyukur. Peneliti juga menambakkan beberapa permainan dan sesi tanya jawab selama pemberian materi. Setelah sesi materi berakhir, peneliti memberikan buku harian bersyukur kepada peserta untuk diisi. Peserta diberikan waktu untuk memberikan umpan balik atau berbagi cerita atau pengalaman selama sesi.

Perlakuan yang diberikan dengan menggunakan strategi atau metode role play, yakni dengan menyediakan naskah cerita yang disesuaikan dengan tujuan dari sesi hari tersebut. Sebelumnya peserta terlebih dahulu diberikan naskah cerita untuk dipelajari di rumah masing-masing. Kemudian, pada hari pelaksanaan peserta diberikan waktu kembali untuk latihan dengan durasi 30-45 menit. Setelah itu, peserta akan menampilkan role play didepan guru dan beberapa siswasiswi di SMP X. pelaksanaan yang sama juga dilakukan untuk bagian strategi atau metode sosiodrama.

Berbeda dengan perlakuan dengan menerapkan strategi latihan keterampilan, yakni peserta diberikan kebebasan untuk menciptakan karya dengan barang-barang bekas untuk dipersembahkan kepada orang yang berjasa atau yang ingin mereka sampaikan "terimakasih". Hasil karya yang dibuat diminta untuk diserahkan kepada orang tersebut dan mengucapkan kalimat rasa bersyukur atau terimakasih peserta terhadap orang tersebut. Pada sesi ini sebelumnya diberikan materi yang disesuiakan dengan topik dan tujuan dari sesi tersebut. Perlakuan dengan menggunakan strategi field trip, yakni peserta mendapatkan kesempatan untuk mengikuti study tour dengan misi tertentu yang dibuat sesuai dengan materi dan tujuan dari sesi tersebut. Perlakuan sama yang diberikan disetiap sesinya, dengan memberikan gratitude jurnal (buku harian bersyukur) untuk diisi oleh setiap peserta. Gratitude jurnal (buku harian bersyukur) dirancang oleh peneliti sebagai salah satu sasaran tugas. Pada tabel 1 berikut merupakan rancangan intervensi yang dirancang oleh peneliti di setiap sesi: 
Tabel 1: Rancangan Intervensi Gratitude

\begin{tabular}{cll}
\hline Sesi & \multicolumn{1}{c}{ Materi } & \multicolumn{1}{c}{ Tujuan Khusus } \\
\hline 1 & Sense of appreciation 1 & $\begin{array}{l}\text { Partisipan dapat menyadari kesenangan-kesenangan sederhana } \\
\text { simple pleasure } \text { yang diperoleh dari Tuhan dan kehidupan. }\end{array}$ \\
\hline 2 & Sense of Appreciation 3 & $\begin{array}{l}\text { Partisipan dapat menyadari kesenangan sederhana yang } \\
\text { diperoleh dari orang lain. }\end{array}$ \\
\hline 3 & Sense of Appreciation 4 & $\begin{array}{l}\text { Partisipan mampu mengakui peran orang lain untuk } \\
\text { kesejahteraannya dan memandang orang lain secara positif. }\end{array}$ \\
\hline 4 & $\begin{array}{l}\text { Perasaan positif terhadap kehidupan } \\
\text { yang dimiliki 1. }\end{array}$ & $\begin{array}{l}\text { Partisipan merasa puas dengan hidupnya (sense of abundance) } \\
\text { dan dapat merasa bahagia dengan keadaan dirinya. }\end{array}$ \\
\hline 5 & $\begin{array}{l}\text { Perasaan positif terhadap kehidupan } \\
\text { yang dimiliki 2 }\end{array}$ & $\begin{array}{l}\text { Partisipan menunjukkan rasa bahagia karena keberadaan orang } \\
\text { lain. }\end{array}$ \\
\hline 6 & $\begin{array}{l}\text { Tindakan sebagai ekspresi dari } \\
\text { perasaan positif dan apresiasi yang } \\
\text { dimilikinya 1. }\end{array}$ & $\begin{array}{l}\text { Partisipan dapat melakukan ibadah sebagai wujud syukur kepada } \\
\text { Tuhan dan dapat menjalani aktivitas sebaik mungkin sebagai } \\
\text { bentuk terimakasih kepada hidup dan Tuhan. }\end{array}$ \\
\hline 7 & $\begin{array}{l}\text { Tindakan sebagai ekspresi dari } \\
\text { perasaan positif dan apresiasi yang } \\
\text { dimilikinya 2 }\end{array}$ & $\begin{array}{l}\text { Partisipan mampu membantu orang lain yang diekspresikan } \\
\text { sebagai rasa terimakasih dan mampu memahami makna } \\
\text { membalas kebaikan orang lain sebagai wujud apresiasi. }\end{array}$ \\
\hline 8 & $\begin{array}{l}\text { Sense of appreciation 2 } \\
\text { martisipan mampu mengakui kebaikan Tuhan untuk } \\
\text { kehidupannya dan memiliki pandangan kehidupan dan Tuhan } \\
\text { secara positif. }\end{array}$ \\
\hline
\end{tabular}

\section{HASIL DAN PEMBAHASAN}

Berdasarkan penggolongan kategori skor harga diri (self-esteem) didapat dari percentiles $27 \%$ batas bawah dan percentiles $73 \%$ percentiles batas atas, didapatkan dari 28 peserta ditemukan 7 siswa yang berada pada kategori harga diri dengan skor rendah. Dari tujuh siswa yang ditetapkan pada awalnya, ternyata hanya diperoleh 6 siswa yang memenuhi kriteria partisipan dalam penelitian yaitu AZA, PAN, RMT, ASY, DAL, dan TUM. Berdasarkan penggolongan tersebut, didapatkan kategori skor rendah, sedang dan tinggi. Ditemukan nilai $27 \%$ ke bawah adalah mulai dari 15.83 dan nilai $73 \%$ ke atas adalah mulai dari 19.00 (Nisfiannoor, 2009).

Intervensi rasa bersyukur (gratitude) membutuhkan waktu kurang lebih sebulan, dengan frekuensi dua-tiga kali seminggu dengan durasi 60-90 menit terkecuali sesi terakhir (sesi kedelapan) dengan menerapkan strategi field trip. Pemberian pelatihan selama delapan sesi intervensi rasa bersyukur (gratitude), keenam partisipan mengalami peningkatan skor. Keenam partisipan juga memberikan hasil evaluasi yang baik terhadap sesi pelatihan kebersyukuran yang telah dilakukan.

Tabel 2. Hasil Pretest dan Posttest Partisipan dengan menggunakan RSES

\begin{tabular}{llllll}
\hline Inisial Subjek & Pretest & Kategori & Posttest & Kategori & Keterangan \\
\hline AZA & 11 & Rendah & 17 & Sedang & Meningkat \\
\hline PAN & 15 & Rendah & 15 & Rendah & Stabil \\
\hline RMT & 12 & Rendah & 13 & Rendah & Meningkat \\
\hline ASI & 14 & Rendah & 18 & Sedang & Meningkat \\
\hline DAL & 12 & Rendah & 13 & Rendah & Meningkat \\
\hline TMY & 13 & Rendah & 15 & Rendah & Meningkat \\
\hline
\end{tabular}

Berdasarkan tabel 2 di atas, terlihat bahwa partisipan mengalami peningkatan pada tingkat skor harga diri, namun harga diri partisipan masih tergolong rendah dan sedang. Peningkatan harga diri dari rendah ke sedang dialami oleh subjek AZA (sebanyak 6 poin) dan ASI (sebanyak 4 poin). Kedua partisipan lainnya mengalami peningkatan, namun tergolong harga diri rendah, sedangkan 
satu subjek masih stabil dengan penggolongan harga diri rendah. Data pre-test dan post-test dari RSES yang diisi oleh keenam partisipan diolah dengan menggunakan uji Wilcoxon Signed Ranks. Taraf nyata yang digunakan adalah $\alpha=0.05$, sehingga apabila hasil uji menunjukkan nilai yang lebih kecil maka dinyatakan bahwa $\mathrm{H}_{0}$ ditolak. Berikut ini merupakan tabel hasil uji statistik yang dilakukan:

Tabel 3 Hasil Uji Wilcoxon Signed Rank

\begin{tabular}{ll}
\hline & Posttest-Pretest \\
\hline $\mathrm{Z}$ & $-2.032^{\mathrm{a}}$ \\
\hline Asymp. Sig. (2-tailed) & 0.042 \\
\hline
\end{tabular}

Berdasarkan hasil uji statistik tersebut, maka dapat disimpulkan adanya efektivitas dari pelatihan kebersyukuran yang diberikan untuk meningkatkan harga diri remaja di SMP terbuka X dengan status sosial ekonomi rendah (Asymp. Sig. $=0.042<0.05$ ).

Intervensi yang diberikan dengan metode sosiodrama pada kelompok eksprimen dapat dikatakan belum mencapai indikator keberhasilan. Pada sesi ini lebih menekankan pada penyampaian materi perasaan positif terhadap kehidupan yang dimiliki. Sebelumnya peneliti memberikan pemaparan melalui sebuah cerita, dengan tujuan peserta mengenal keunggulan atau hal positif yang dimiliki. Berdasarkan cerita tersebut, peneliti meminta partisipan untuk mengeksplorasi cerita. Partisipan diberi tanggung jawab untuk menuliskan naskah drama dan ditampilkan didepan orang lain. Ada kemungkinan, dengan membebaskan partisipan untuk menuliskan naskah cerita, peserta kurang memahami perintah yang diberikan guru maupun peneliti.

Kemungkinan lainnya juga, cara pandang partisipan mendefinisikan rasa puas terhadap hidup yang mereka miliki. Bagi partisipan rasa puas terhadap hidup mereka adalah ketika mereka dapat mencapai cita-cita mereka, sehingga, indikator jenis bersyukur transpersonal, yang menekankan pada penyampaian materi agar partisipan dapat memahami ungkapan terimakasih mereka yang ditujukkan kepada Tuhan dan memahami kekuatan yang lebih besar dari dirinya atau alam semesta belum menunjukkan adanya peningkatan secara signifikan. Hal ini mungkin saja terjadi dengan beberapa konsekuensi psikologis jika seseorang berada di kondisi miskin, dengan keadaan yang tidak memiliki apa-apa yang mereka dapat harapkan agar mereka menjadi sukses. Hal ini juga dikarenakan orang yang tergolong miskin cenderung mendengar bahwa mereka cocok dengan keadaan yang tidak memiliki apa-apa, tidak dapat belajar, bodoh atau tidak berprestasi, malas, dan tidak produktif., sehingga mereka berakhir dengan keyakinan bahwa mereka tidak memiliki kemampuan.

Temuan lain dari penelitian ini, dari enam partisipan yang mengikuti pelatihan gratitude, terdapat satu partisipan yang tidak mengalami peningkatan skor harga diri. Hal ini dikarenakan dari delapan sesi pertemuan, salah satu partisipan tidak mengikuti intervensi rasa bersyukur (gratitude) sebanyak satu kali pertemuan. Adapun hal ini dianggap sebagai kekurangan yang tidak dapat di kontrol oleh peneliti. Rendahnya komitmen untuk berubah merupakan salah satu karakteristik dari remaja dengan harga diri (self-esteem) yang rendah. Pada saat kesepakatan di awal, partisipan menyetujui untuk mengikuti setiap sesi. Akan tetapi, pada pelaksanaannya terjadi hambatan yang dialami oleh partisipan. Partisipan merupakan siswa kelas siang, sudah menjadi kebiasaan partisipan bangun siang, sedangkan pelaksanaan intervensi berlangsung di pagi hari. 


\section{KESIMPULAN DAN SARAN}

Hasil penelitian dengan memberikan intervensi rasa syukur (gratitude) selama delapan sesi pertemuan, menunjukkan bahwa tingkat harga diri partisipan mengalami peningkatkan. Hal ini sejalan dengan penelitian-penelitian sebelumnya yang menyatakan bahwa adanya hubungan positif antara gratitude dan self-esteem. Penelitian sebelumnya yang dilakukan oleh Kong, Ding, dan Zhao (2015) di kalangan mahasiswa sarjana menguji dukungan sosial dan harga diri dalam hubungan antara rasa syukur dan kepuasan hidup. Hasil penelitian menunjukkan bahwa orang yang bersyukur memiliki kecenderungan untuk memiliki tingkat harga diri yang lebih tinggi (Kong et al., 2015). Bahkan, harga diri secara teoritis dan secara empiris berkontribusi pada kepuasan hidup (Chan, 2013). Dengan demikian, gratitude cenderung dikaitkan dengan tingkat kepuasan hidup yang lebih tinggi dengan rasa harga diri yang lebih besar.

Seiring waktu, mekanisme sosiometer ini dapat mengarah pada efek memperluas dan membangun dalam meningkatkan self-esteem seseorang. Khususnya, mereka yang memiliki rasa syukur yang tinggi lebih mungkin untuk memperluas modal sosial mereka, karena mereka cenderung memiliki pandangan dunia yang fleksibel. Dengan tujuan untuk mengenali dan menafsirkan hal-hal yang mereka miliki dalam hidup sebagai hadiah bahkan dalam keadaan negatif (L. H. Chen \& Wu, 2014). Berdasarkan penelitian yang telah dilakukan, maka diharapkan penelitian selanjutnya yang ingin meneliti keefektifan intervensi rasa bersyukur (gratitude) untuk meningkatkan harga diri dapat menambahkan jumlah responden dalam satu kelompok eksperimen atau membandingkan dengan karakteristik yang berbeda. Penelitian selanjutnya juga diharapkan dapat menguji kembali modul gratitude yang dirancang oleh peneliti. Penelitian lebih lanjut memberi kita lebih banyak wawasan tentang topik ini, khususnya dari perspektif sosiokultural Indonesia.

\section{Ucapan Terima Kasih}

Peneliti menyadari keberhasilan penyusunan ini tidak terlepas dari bantuan dari berbagai pihak baik langsung, maupun tidak langsung. Pada kesempatan ini, peneliti ingin menyampaikan rasa terimakasih kepada pihak SMP Terbuka X di Jakarta Utara yang memberikan ijin kepada peneliti untuk melaksanakan penelitian di sekolah yang bersangkutan, selain itu terimakasih kepada segenap guru yang terlibat membantu dan bekerjasama dalam penelitian ini.

\section{REFERENSI}

Aunillah, F., \& Adiyanti, M. G. (2015). Program Pengembangan Keterampilan Resiliensi untuk Meningkatkan Self-esteem pada Remaja. Gadjah Mada Journal of Professional Psychology, 1(1), 48-63.

Chan, D. W. (2013). Counting blessings versus misfortunes: Positive interventions and subjective well-being of Chinese school teachers in Hong Kong. Educational Psychology, 33(4), 504519. https://doi.org/10.1080/01443410.2013.785046

Chen, L. H., \& Wu, C. H. (2014). Gratitude Enhances Change in Athletes' Self-Esteem: The Moderating Role of Trust in Coach. Journal of Applied Sport Psychology, 26(3), 349-362. https://doi.org/10.1080/10413200.2014.889255

Chen, W., Niu, G. F., Zhang, D. J., Fan, C. Y., Tian, Y., \& Zhou, Z. K. (2016). Socioeconomic status and life satisfaction in Chinese adolescents: Analysis of self-esteem as a mediator and optimism as a moderator. Personality and Individual Differences, 95, 105-109. https://doi.org/10.1016/j.paid.2016.01.036

Cunha, L. F., Pellanda, L. C., \& Reppold, C. T. (2019). Positive psychology and gratitude interventions: A randomized clinical trial. Frontiers in Psychology, 10(MAR), 1-9. https://doi.org/10.3389/fpsyg.2019.00584 
Fanti, K. A., \& Henrich, C. C. (2015). Effects of Self-Esteem and Narcissism on Bullying and Victimization During Early Adolescence. Journal of Early Adolescence, 35(1), 5-29. https://doi.org/10.1177/0272431613519498

Gabana, N. T., Steinfeldt, J., Wong, Y. J., Chung, Y. B., \& Svetina, D. (2018). Attitude of Gratitude: Exploring the Implementation of a Gratitude Intervention with College Athletes. $\begin{array}{lllll}\text { Journal of Applied Sport } & \text { Psychology, } & 000),\end{array}$ https://doi.org/10.1080/10413200.2018.1498956

Ghosh, A., \& Deb, A. (2017). An exploration of gratitude themes and suggestions for future interventions. Journal of Human Behavior in the Social Environment, 27(7), 678-693. https://doi.org/10.1080/10911359.2017.1323068

Grimaldy, D., Chris, H., \& Nirbayaningtyas, R. (2018). Efektivitas jurnal kebahagiaan dalam meningkatkan self esteem pada anak jalanan. March. https://www.researchgate.net/publication/323934531_EFEKTIVITAS_JURNAL_KEBA HAGIAAN_DALAM_MENINGKATKAN_SELF_ESTEEM_PADA_ANAK_JALANA $\mathrm{N}$

Karadağ, E. (2017). The factors effecting student achievement: Meta-analysis of empirical studies. The Factors Effecting Student Achievement: Meta-Analysis of Empirical Studies, May 2017, 1-337. https://doi.org/10.1007/978-3-319-56083-0

Kong, F., Ding, K., \& Zhao, J. (2015). The Relationships Among Gratitude, Self-esteem, Social Support and Life Satisfaction Among Undergraduate Students. Journal of Happiness Studies, 16(2), 477-489. https://doi.org/10.1007/s10902-014-9519-2

Listiyandini, R. A., Nathania, A., Syahniar, D., Sonia, L., \& Nadya, R. (2015). Mengukur Rasa Syukur : Pengembangan Model. Jurnal Psikologi Ulayat, 2(2), 473-496.

McCullough, M. E., Kilpatrick, S. D., Emmons, R. A., \& Larson, D. B. (2001). 8McCulloughGratitudeMoralAffect.pdf. In Psychological Bulletin (Vol. 127, Issue 2, p. 249). http://psycnet.apa.org/journals/bul/127/2/249/

Mruk, C. (2006). Self-esteem Research, Theory, and Practice (3rd ed.). Spinger Publishing Company, Inc.

Nadya, R., Syahniar, D., Listiyandini, R. A., Sonia, L., \& Nathania, A. (2017). Mengukur Rasa Syukur: Pengembangan Model Awal Skala Bersyukur Versi Indonesia. Jurnal Psikologi Ulayat, 2(2), 473. https://doi.org/10.24854/jpu22015-41

Nisfiannoor, M. (2009). Pendekatan Statistika Modern. Salemba Huamanika.

O'Connell, B. H., O’Shea, D., \& Gallagher, S. (2017). Feeling Thanks and Saying Thanks: A Randomized Controlled Trial Examining If and How Socially Oriented Gratitude Journals Work. Journal of Clinical Psychology, 73(10), 1280-1300. https://doi.org/10.1002/jclp.22469

Oktalia, Beta, Tiatri, S., \& Mularsih, H. (2018). Efektivitas Program Psikoedukasi Pengembangan Self-Esteem Untuk Meningkatkan Self-Esteem Remaja Kelas 1 Di Smp X. Jurnal Muara $\begin{array}{lllll}\text { Ilmu Sosial, Humaniora, Dan } & & \end{array}$ https://doi.org/10.24912/jmishumsen.v2i2.2301

Oktalia, Betta. (2018). Efektivitas Program Psikoedukasi Pengembangan Self-esteem untuk Meningkatkan Self-Esteem Remaja Kelas 1. Universitas Tarumanagara.

Orth, U., \& Robins, R. W. (2013). Understanding the Link Between Low Self-Esteem and Depression. Current Directions in Psychological Science, 22(6), 455-460. https://doi.org/10.1177/0963721413492763

Papalia, E, D., \& Feldman, Ruth, D. (2014). Perkembangan Manusia (12th ed.). Salemba Humanika. 
Rash, J. A., Matsuba, M. K., \& Prkachin, K. M. (2011). Gratitude and well-being: Who benefits the most from a gratitude intervention? Applied Psychology: Health and Well-Being, 3(3), 350-369. https://doi.org/10.1111/j.1758-0854.2011.01058.x

Sang, C. C. (2015). Relationship between students' family Socio-economic Status, Self esteem. International Journal of Education and Research, 3(2), 647-656. www.ijern.com

Simpson-Scott, L. (2009). Self-perceived information seeking skills and self-esteem in adolescents by race and gender. ProQuest Dissertations and Theses, 107. http://login.ezproxy.library.ualberta.ca/login?url=http://search.proquest.com/docview/304 962226?accountid=14474\%5Cnhttp://resolver.library.ualberta.ca/resolver?url_ver=Z39.8 8-2004\&rft_val_fmt=info:ofi/fmt:kev:mtx:dissertation\&genre=dissertations+\&+theses\&

Trzesniewski, K. H., Donnellan, M. B., Moffitt, T. E., Robins, R. W., Poulton, R., \& Caspi, A. (2006). Low self-esteem during adolescence predicts poor health, criminal behavior, and limited economic prospects during adulthood. Developmental Psychology, 42(2), 381-390. https://doi.org/10.1037/0012-1649.42.2.381

Uhder, J., McMinn, M. R., Bufford, R. K., \& Gathercoal, K. (2018). A Gratitude Intervention in a Christian Church Community. Journal of Psychology and Theology, 45(1), 46-57. https://doi.org/10.1177/009164711704500104

Veselska, Z., Madarasova Geckova, A., Gajdosova, B., Orosova, O., Van Dijk, J. P., \& Reijneveld, S. A. (2010). Socio-economic differences in self-esteem of adolescents influenced by personality, mental health and social support. European Journal of Public Health, 20(6), 647-652. https://doi.org/10.1093/eurpub/ckp210 